\title{
Al-Madãris
}

VOL. 2, NO. 2, 2021

E-ISSN: 2745-9950

https:/journal.staijamitar.ac.id/index.php/almadaris

\section{TRANSFORMASI PENDIDIKAN ISLAM PERSPEKTIF HUKUM TIGA TAHAP AGUSTE COMTE}

\author{
Hamdan Adib \\ UIN Prof KH Saifuddin Zuhri \\ Adib.hamdan123@gmail.com
}

\begin{abstract}
This study aims to examine the transformation of Islamic education in terms of Auguste Comte's three-stage law. This study uses a qualitative approach with the type of research is library research. The results of this study are that the theological stage occurred when the emergence of the first Islamic boarding school in the form of a Salaf Islamic Boarding School whose focus of study was only on theological aspects or aspects of life after death. then the metaphysical stage shows the use of reason to answer problems that occur in humans both at the theological level as well as worship and muamalah. then the positive stage where humans have considered scientific facts in solving Islamic problems, namely the emergence of offers of humanist meanings of Islam such as pluralism and Islamic archipelago. The emergence of Islamic higher education institutions has also become a forum for discussing scientific answers by academics who have professional qualifications and competencies.
\end{abstract}

Keywords: Transformation;Islamic education; Three Stage Law

\section{A. Pendahuluan}

Transformasi Pendidikan Islam sampai saat ini masih terus terjadi, diawali dari adanya masjid sebagai lembaga pendidikan Islam pertama disamping tempat kediaman ulama atau mubaligh (Tohir \& M. Syukri Azwar Lubis, 2020). Masjid juga merupakan lembaga pendidikan pada masa Rasulullah. Sedangkan di Indonesia dikenal lembaga pendidikan Pesantren di Pulau Jawa, di Aceh ada Dayah atau Rangkang, dan di Minangkabau ada Surau (Hariadi, 2015). 
Perkembangan selanjutnya pesantren menyebar di seluruh Nusantara dengan berbagai bentuk mulai dari Salaf, semi Kholaf dan Kholaf.

Transformasi selanjutnya muncul dengan adanya lembaga pendidikan klasikal yaitu madrasah dengan tema kajian keislaman dan terus berkembang sampai ada lembaga pendidikan formal yang kajiannya sudah terintegrasi antara pendidikan keislaman dan pendidikan dengan materi umum. Ini menandakan islam selalu bertransformasi sesuai dengan kebutuhan dan mencoba menjawab tuntutan zaman.

Transformasi ini bisa dilihat melalui teori-teori yang dimiliki oleh para tokoh misalnya dilihat dengan teori perubahan sosial yaitu dengan memperhatikan perubahan masyarakat yang turut andil dalam membangun perubahan pendidikan islam. teori lain yang digunakan adalah teori genealogi foucault yaitu dengan memperhatikan relasi kuasa antara pengetahuan dan kekuasaan yang ada dalam pendidikan Islam itu sendiri.

Penelitian ini menggunakan teori Hukum Tiga Tingkatan yang digunakan untuk melihat transformasi pendidikan Islam. teori ini dikemukakan oleh Auguste Comte dimana Comte melihat perubahan manusia melalui pola pemikiran yang dimilikinya. Pemikiran ini diawali oleh pemikiran teologis kemudian dilanjutkan dengan pemikiran mistik dan pada akhirnya menuju pada pemikiran positif yang dianggap sebagai pemikiran final dalam pemikiran manusia.

Penelitian yang sama sudah pernah dilakukan oleh Nur Syarifuddin yang membahas mengenai transformasi pendidikan Islam dilihat dari madrasah secara historis. Selanjutnya syarifuddin menjelaskan bahwasannya madarasah merupakan hasil integrasi antara pesantren dan juga pendidikan formal dengan dasar pelaksanaanya adalah SKB 3 mentri (Syarifuddin, 2017). Penelitian lainnya dilakukan oleh Ali Muzakir dimana dalam penelitiannya Muzakir menjelaskan bahwa transformasi pendidikan Islam di Jambi bermula dari madrasah dengan sistem pendidikannya adalah pondok, murid, adanya tuan guru (kiai) dan kitab kuning, dengan tidak adanya masjid. Selanjutnya Muzakir menjelaskan bahwasannya madrasah merasa khawatir dengan perubahan yang dilakukan khususnya berkaitan dengan sistem pedidikan (Muzakir, 2017).

Penelitian ini memiliki perbedaan dengan penelitian yang sudah dilakukan dimana penelitian ini berfokus pada kajian historis trasformasi pendidikan islam dengan melihatnya melalui teori Hukum Tiga Tahap. Penelitian ini juga penting untuk dilakukan karena dengan mengetahui tahapan pemikiran yang ada pada tiap bentuk transformasi bisa dijadikan refleksi untuk melakukan transformasi berikutnya dengan lebih baik dan bebas dari kesalahan transformasi sebelumnya.

\section{B. Review Literatur}

\section{Transformasi Pendidikan Islam}

Transformasi pendidikan Islam di maknai dengan upaya yang dilakukan oleh pendidik terhadap peserta didik agar pendidikan Islam mencapai sasaran sesuai dengan yang dicita-citakan.(Idris, Willya, \& Rumondor, 2020). Upaya yang dilakukan ini salah satunya dengan mendirikan lembaga pendidikan yang mampu bersaing dengan lembaga pendidikan formal dan tetap mampu menyikapi dengan baik pesatnya arus globalisasi. 
Lembaga pendidikan yang dihadapkan dengan efek dari globalisasi yaitu transformasi budaya yang terjadi pada abad 21 ini akan membawa kepada pengembangan yang berwawasan transformatif. Pengembangan ini sangat dibutuhkan karena kebanykan lembaga pendidikan Islam masih terbatas pada mempertahankan yang baik dari masa silam dan belum membuka diri untuk mengambil yang baru dan yang lebih baik (Idris et al., 2020). Salah satu contohnya adalah masih adanya lembaga pendidikan pesantren yang masih menutup diri pada kecanggihan internet dan membatasi santrinya untuk tidak berkomunikasi dan berkenalan dengan internet. keberadaan internet sendiri akan meningkatkan linterasi digital yang ada dalam suatu lembaga pendidikan. Jejen Musfah menjelaskan bahwasannya pesantren saat ini harus meningkatkan literasi digitalnya namun sayangnya sampai saat ini masih banyak pesantren yang tidak mempunyai fasilitas laboratorium komputer yang memadai (Permana, 2019).

Pesantren yang tidak mempersilahkan santrinya memanfaatkan internet biasanya ada pada pesantren salaf, dimana pesantren salaf yaitu bentuk asli dari pesantren sejak pertama kali didirikan. Pesantren salag adalah pesantren yang kurikulumnya murni mengajarkan bidang studi ilmu agama saja baik melalui sistem madrsah diniyah maupun pengajian sorogan dan bandongan (Tohir \& $\mathrm{M}$. Syukri Azwar Lubis, 2020). Perkembangan selanjutnya pesantren memiliki bentuk baru yang selanjutnya disebut dengan pesantren modern. Pesantren dengan bentuk modern ini sudah memiliki sistem pembelajaran yang beragam (Sudrajat, 2018). Komponen pesantren yang tidak hanya kiai, santri, kitab kuning, masjid dan pondok (Mubarak, 2019) namun juga di lengkapi dengan lembaga pendidikan formal dengan fokus kajian tidak terpusat pada kajian keagamaan saja, namun juga ada pada lembaga pendidikan formal dengan sistem pendidikan kelas dan penekanan pada penguasaan bahasa.

Melalui perkembangan ini pendidikan Islam sudah terlihat tidak hanya berpaya dalam mengkaji kajian agamis teosentris dan akhlak namun juga mempersiapkan santrinya dalam membina dan mengembangkan ilmu pengetahuan dan teknologi serta kesiapan santri dalam berpacu pada kompetensi dunia global.

Perkembangan selanjutnya dari pendidikan Islam masuk pada lembaga pendidikan formal. Hal ini diatur di dalam PP No 5 Tahun 2007 yang menjelaskan bahwa setiap satuan pendidikan pada semua jalur, jenjang dan jenis pendidikan wajib menyelenggarakan pendidikan agama termasuk di dalamnya pendidikan agama islam (PERATURAN PEMERINTAH REPUBLIK INDONESIA NOMOR 55 TAHUN 2007, n.d.). melalui peraturan pemerintah ini lembaga pendiidkan dalam menjalankan pendidikannya memiliki badan hukum yang jelas.

Tidak hanya sampai disini transformasi pendidikan Islam juga memunculkan adanya perguruan tinggi keislaman negeri. PTKIN sendiri merupakan perguruan tinggi di indonesia yang pengelolaanya berada di bawah kementrian Agama yang sampai saat ini memiliki tiga jenis yaitu Universitas Islam Negeri, Institut Agama Islam Negeri dan juga Sekolah tinggi Agama Islam Negeri (Sholehuddin, 2019). Munculnya PTKIN ini tidak lepas dari berbagai hal diantaranya yaitu membentengi diri dari maraknya kaum kristiani yang muncul dan mendirikan perguruan tinggi dengan biaya yang rendah dan dikelola oleh akademisi berpendidikan tinggi maka pendidikan Islam juga perlu untuk di 
adakan. Faktor lainnya yaitu respon atas kebutuhan masyarakat untuk merealisasikan kehidupan beragama di tanah air dan masuknya pengaruh idepembaharuan pemikiran Islam ke Indonesia. Maka pada 8 Juli 1946 didirikanlah Sekolah Tinggi Islam di Jakarta di bawah pimpinan Prof Abdul Kahar Muzakkir (Sholehuddin, 2019).

Melalui deskripsi yang sudah diberikan maka pendidikan Islam dapat dikategorikan dalam tiga hal yaitu lembaga, mata pelajaran dan value. Sebagai lembaga pendidikan Islam jelas berorientasi pada adanya pesantren, madrasah, sekolah islam, dan perguruan tinggi Islam. pada mata pelajaran dimana setiap materi yang diajarkan tidak lepas dari materi yang membahas mengenai agama Islam baik dari sisi amaliah sampai kepada adab berperilakunya dan juga nilainilai yang terkandung di dalamnya.(Daulay, 2019).

\section{Hukum Tiga Tahap}

Auguste Comte yang juga dikenal sebagai bapak sosiologi juga menjadi pelopor dari teori Positivisme dimana dalam positivisme ini mengutamakan pengalaman obyektif sehingga pengalaman subyektif dan batiniah di kesampingkan. Ciri positivisme yang sangat tampak ialah nisbi, organik, terperinci, pasti, berguna dan yang paling penting adalah nyata (Maulana, 2009). Munculnya sosiologi sebagai sebuah disiplin ilmu baru tidak lepas dari peran positivisme yang menuntut sains yaitu fisika dan biologi diterapkan pada pola hidup manusia. Selain sebab kebutuhan ilmu pengetahuan munculnya sosiologi juga diakibatkan oleh pergolakan yang terjadi di prancis. demi mendapatkan kehidupan yang teratur masyarakat diancam baik dari sosial politik maupun intelektual. Hal ini memunculkan kaum intelekual yang masih memegang keinginan dan keyakinan untuk kembali kearah abad pertengahan dan ini menjadi kritikan Comte bahwa keinginan itu merupakan hal yang absurd dan mustahil karena pada abad pencerahan sudah terjadi kemajuan pada bidang keilmuan dan industri (Chabibi, 2019).

Comte juga merumuskan perkembangan intelektual manusia yang masyhur disebut dengan Hukum tiga tahap. Hukum ini menjelaskan perkembangan intelektual pada kehidupan manusia yang terbagi kedalam tiga tahapan. tiga tahap perkembangan ini akan berkembang ke dalam pemikiran manusia secara individual maupun kolektif seluruh umat manusia. Tiga tahapan dalam perkembangan ini yaitu teologis, metafisis, dan positif atau ilmiah (Astini $\&$ Arsadi, 2021).

Ketiga tahapan ini yaitu (Nurianto Rachmad Soepadmo, 2020): pertama, Tahap Theologi (Theological) pada tahap ini tingkat pemikiran manusia ada pada anggapan bahwa semua benda di dunia mempunyai jiwa atau ruh, dan itu disebabkan oleh kekuatan yang berada di atas alam manusia (kekuatan supranatural, adikodrati) (Suryono, 2019). Melalui bukti yang ada diketahui bahwa perkembangan ilmu pengetahuan dimulai pada $6 \mathrm{SM}$, ketika manusia dan peradaban besar asia kecil mulai bertanya tentang hakikat alam. Lebih jauh bangsa Mesir dan Babylonia telah mempelajari matematika, astronomi, dan kedokteran dengan kemajuan yang mengagumkan.

Perkembangan pengetahuan pada permulaan ini memiliki ciri:1) orientasi pengetahuannya adalah objek yang bersifat kosmologis-religius, yaitu objek 
pengetahuan yang berhubungan dengan alam keseluruhan dengan sifat-sifatnya yang religius. 2) pengembangan pengetahuan ini merupakan proses pendidikan yang dianggap sakral dan karenanya hanya melibatkan kalangan pendeta. 3) perkembangan pengetahuan di dasarkan pada usaha untuk menggali jawaban atas pertanyaan yang diajukan. Tidak ada catatan yang menerangkan bahwa dalam pemberian jawaban mengalami perdebatan dimana mereka sudah cukup dan puas dengan jawaban yang diberikan (Huda, 2020).

Pemahaman manusia pada tahap theologi juga terbagi kedalam tiga tataran, yaitu: 1) Fetisysme, yaitu pemahaman dimana segala sesuatu di sekeliling manusia mempunyai suasana kehidupan yang sama seperti manusia dan juga mempengaruhi kehidupan manusia sehingga harus menyesuaikan diri. 2) Politeisme, yaitu pemahaman bahwasannya daya kekuatan penentu tidak berasal dari benda-benda di sekeliling manusia, tetapi dari makhluk yang tidak kelihatan yang berada di sekeliling manusia sehingga harus menyesuaikan dengan makhluk yang tidak kelihatan tersebut. 3) monoteisme yaitu pemahaman bahwa kekuatan penentu tidak berasal dari makhluk yang tidak kelihatan, tetapi berasal dari Tuhan yang maha Esa (U Hasanah, Suatuti, \& Rahayu, 2020).

Kedua, bersifat metafisik (Metaphysucal), tahap ini disebut juga tahap peralihan dan terjadi antara tahun 1300-1800 M (Ulfatun Hasanah, 2019). Pada tahap ini jiwa manusia telah mampu melepaskan diri dari kekuatan adikodrati, dan beralih ke kekuatan abstraksi ditandai dengan ditinggalkannya dogma agama dan kemampuan akal budi manusia dikembangkan(U Hasanah et al., 2020). Pada saat ini istilah ontologi mulai dipergunakan.

Akal budi merupakan satu-satunya kekuatan yang dipergunakan manusia untuk menjelaskan adanya segala sesuatu, sehingga berkat kemampuan abstraksi tersebut, manusia mampu pula untuk menerangkan hakikat atau substansi dari segala sesuatu yang ada (Munir, 2018). Salah satu bentuk nyata sampai saat ini masih digunakan sebagai hasil dari perkembangan pada tahap ini yaitu munculnya hak-hak manusia (de droit d'homme) dimana hak asasi manusia ini tidak dapat dibuktikan secara ilmiah (Nurianto Rachmad Soepadmo, 2020).

Ketiga, bersifat positif atau ilmiah (Scientific), tahap ini merupakan puncak perkembangan manusia yang ditandai kepercayaan yang tinggi terhadap ilmu. Dari sisi waktu, tahap ini yang dimulai pada 1800 yang memang di sekitar tahun ini terjadi banyak perubahan radikal atau revolusi termasuk di bidang ilmu. Perkembangan di bidang ilmu sebagai ikon pada tahapan ini dengan sendirinya berdampak pada semakin tergerusnya kepercayaan manusia terhadap kekuatan pada dua tahap sebelumnya, metafisik dan juga teologis (S. Arifin, 2018).

Lebih jauh pada tahap ini Comnte menjelaskan bahwa akan muncul agama humanitis (agama kemanusiaan), kemudian sosiolog akan menjadi pendeta agama baru yang akan membimbing manusia dalam kehidupan yang harmonis. Sosiolog akan mengajari manusia untuk (berfikir positif berfiir ilmial) dan menghubungkan doktrin cinta, keteraturan, dan kemajuan dengan kehidupan manusia. agama humanitas ini diharapkandapat menjamin terwujudnya suatu keteraturan sosial dalam masyarakat positif ini (Sriyani, 2020).

Melalui hukum tiga tahap tersebut, Comte melihat sejarah perkembangan manusia berlangsung di atas garus lurus menuju ke arah kemajuan. Makna perkembangan dalam hukum tiga tahap bersifat positif dalam arti suatu 
kemajuan. Masyarakat masa depan yang telah sampai pada tahap positif itu menurut Comte merupakan masyarakat yang terbaik dan ideal. Pada tahap ini kehidupan masyarakat akan diatur oleh kaum elit cendikiawan industrialis dengan sikap yang rasional dan ilmiah yang berdasarkan cinta kasih sebagai pedomannya, ketertiban sebagai landasannya dan kemajuan sebagai tujuannya.

\section{Metodelogi}

Pendekatan penelitian yang digunakan pada penelitian ini ialah kualitatif deskriptif. Landasan penelitian kualitatif adalah filsafat post positifisme dan kondisi yang diteliti merupakan kondisi alamiah dan peneliti berperan sebagai intrumen itu sendiri (human instrumen), biasanya teknik yang digunakan dalam mengumpulkan data berupa trianggulasi atau gabungan, dan analisisnya bersifat induktif dimana hasil yang di dapatkan menekankan makna daripada generalisasi (Sugiyono, 2008). Kemudian, penelitian ini berada dalam kategori library research dimana dalam upaya pengumpulan datanya dihimpun dari berbagai literature yang ada di perpustakaan atau tempat lainnya yang tidak terbatas hanya pada buku bacaan saja namun juga berbagai bahan dokumen lainnya (Nawawi, 2005).

Setelah mendapatkan data yang dibutuhkan, kemudian dilakukan analisis data. Analisis yang digunakan dalam penelitian ini yaitu analisis isi (Conten Analisis). Analisis isi sendiri diartikan dengan cara dalam menganalisis mengenai konten pesan ketika diskusi. Cara yang digunakan dalam melakukan analisis konten yaitu:1) mengklasifikasikan tanda yang digunakan dalam berkomunikasi, 2) menentukan kriteria untuk mengklasifikasikan data, 3) menggunakan teknik analisis yang sudah baku dalam penentuan prediksi.

Pada penelitian ini peneliti akan mengumpulkan data berupa dokumen yang berasal dari jurnal, buku dan berbagai literatur lainnya yang berkaitan dengan transformasi pendidikan Islam dan Hukum Tiga tahap. Setelah data terkumpul, kemudian dilanjutkan dengan analisis data dengan menggunakan teknik konten analisis.

\section{Hasil Penelitian dan Pembahasan}

Di bagian hasil penelitian, rangkum data yang dikumpulkan dan analisis dilakukan pada data yang relevan dengan masalah yang akan diikuti. Temuan harus jelas dan singkat. Ditulis secara objektif dan faktual, dan tanpa mengungkapkan pendapat pribadi. Ini termasuk angka, tabel, dan gambar (mis., Bagan dan grafik). Tabel angka dan gambar secara berurutan sesuai dengan penampilannya dalam teks.

Transformasi pendidikan Islam di Indonesia bisa dipahami dengan menggunakan teori tiga tahapan milik auguste comte, dimana pada hal ini dilihat dari pendidikan Islam yaitu, pertama pada tahap teologis, dimana manusia pada tahap ini mendasarkan pemikiran pada kekuatan dasar yang ada diatas manusia yang menyebabkan bergeraknya segala benda dan mengatur semua benda yang ada di dunia ini (Suryono, 2019). Jika melihat fokus manusia pada tahap teologis ini, maka dapat diketahui bahwasannya ini memiliki relevansi dengan fokus kajian pesantren salaf atau pesantren bentuk pertama yang ada di indonesia. 
Pesantren tegalsari yang didirikan pada 1742-1862 menjadi salah satu pesantren yang berbentuk salaf(PUSARAN, 2018).

Bentuk pesantren salaf menekanakn kepada penguasaan ilmu agama melalui kitab klasik, tidak mementingkan ijazah dan metode yang digunakan adalah wetonan dan sorogan (Anam, 2017). Pesantren salaf ini pada awal kemunculannya berada di pedesaan sehingga benuk awal ini mencerminkan kebersahajaan, kesederhanaan dan keikhlasan murni (Zuhriy, 2011). Jika di lihat lebih mendalam, nilai nilai pendidikan yang diajarkan di pesantren salaf di dominasi untuk mendapatkan kehidupan yang aman di dunia dan di akhirat kelak dengan didominasi oleh pendidikan agama yang berguna bagi kehidupan akhirat. Hal ini dibuktikandengan bidang keilmuan yang diajarkan seperti ushul fikih, ilmu fikih, ilmu tarikh, akhlak, ilmu musthalah hadits, hadits, tafsir, ulumul Qur'an, al Qur'an, balaghoh, dan ilmu alat seperti nahwu dan juga sharaf (Ibrahim, 2014).

Pesantren salaf juga diarahkan sebagai bentuk lembaga pendidikan yang mengikuti ajaran ulama generasi sahabat, tabi'in, tabi'it tabi'in yang mempunyai kecenderungan pada penafsiran teks secara normatif dan kurang memberikan apresiasi budaya setempat, dan kurang memberikan apresiasi budaya yang tidak sesuai dengan zaman salafus sholih (Z. Arifin, 2012). Hal ini dibuktikan dengan penolakan pesantren pada kalangan reformis salah satunya adalah dengan penolakan yang dilakukan pada sistem pendidikan formal. Hal ini didasari pada pemikiran bahwa kewajiban utama manusia adalah memperlajari ilmu agama berypa ilmu tauhid dan fikih (Solichin, 2015). Sedangkan ilmu umum tidak dibutuhkan sampai muncul stigma "ora dadi pitakon kubur"

Kedua, tahap metafisik, pada tahap ini manusia sudah mulai memanfaatkan akal budi yang dimilikinya, hal ini ditandai dengan pelepasan manusia pada kekuatan adikodrati dan beralih pada kekuatan abstraksi manusia (U Hasanah et al., 2020). Pada transformasi pendidikan Islam kekuatan adikodrati tidak bisa dilepaskan. Penggunaan akal budi tidak bisa lepas dari adanya realitas adikodrati yang tetap menjadi sumber sebab utama terjadinya segala hal yang ada di dunia ini. Kekuatan abstraksi manusia juga tidak bisa digunakan untuk menyangkal sifat Tuhan karena Tauhid sudah dianggap final. keberanian yang bisa dilakukan hanya menarik sifat tuhan kedalam diri manusia seperti yang dilakukan oleh Hassan Hanafi dimana dia berpendapat bahwa kajian teologi yang ditawarkan ulama klasik perlu adanya inovasi dan evolusi dengan nuansa pembebasan. Pembebasan yang dimaksud adalah merubah teologi yang fokus kajiannya pada tataran langit (teosentris) menuju sifat yang lebih membumi (antroposentris) agar bisa dilaksanakan oleh kehidupan manusia sehari-hari (Haq, 2020). Hal ini mulai menandakan adanya proses pemikiran yang lebih maju dari hanya tunduk dan patuh kepada apa yang sudah diberikan sebelumnya dalam kajian kajian keislaman.

Kajian pemikiran manusia pada tahap abstraksi juga ada pada tataran pelaksanaan ibadah dan juga hubungan dengan manusia lainnya (fikih ibadah dan muamalah) tidak luput dari fokus kajian akal budi manusia. Tahap kedua ini juga memunculkan lembaga pendidikan Islam yang sudah mulai mau mengadopsi pemikiran barat misalnya mulai adanya sistem pendidikan yang dilakukan secara klasikal, pencampuran antara wanita dan pria dalam suatu lembaga pendidikan 
baik madrsah ataupun sekolah formal dan juga pendirian lembaga keuangan dengan mempertahankan sistem yang diperbolehkan menurut Islam.

Ketiga, tahap positif dimana manusia mulai berpiki secara ilmiah atau nyata (Suryono, 2019). Pada tahap ini Comte juga menjelaskan akan munculnya agama humanis yang mana dalam pendidikan Islam akan muncul pemikiran yang memberikan tawaran kepada Islam untuk mencerminkan Islam sebagai suatu agama dengan berbagai pandangan. Salah satu hal yang ditawarkan adalah munculnya pemikiran pluralisme agama yang di bawa oleh Nurcholis Majdid dimana fokus pemikiranya sudah lebih berkembang tidak hanya pada tataran ibadah atau muamalah saja namun lebih ke pemaknaan islam sebagai suatu agama yang dipahami kembali dengan agama yang humanis yaitu agama yang universal dan keuniversalannya mencakup pada aspek kehidupan manusia sehingga manusia juga harus memunculkan sikap toleran pada keadaan yang berbeda (Moko, 2017).

Tawaran lainnya yang diberikan adalah Islam Nusantara yang di tawarkan oleh kalangan Nahdlatul Ulama. Islam Nusantara muncul akibat darimaraknya sikap takfiri dan perilaku keislaman yang jumud. Islam nusantara digadanggandang menjadi peluang bagi dunia Islam secara global yang sedang dirundung Ekstrmisme dengan menawarkan keberislaman yang moderat, toleran dan sadar akan kebudayaan (Tempo, 2020).

Kemuculan tahap ketiga ini juga membentuk lembaga pendidikan Tinggi. Dalam pendidikan tinggi sudah tidak lagi hanya memikirkan pengembangan pendidikan islam yang mempertahankan keilmuan klasik saja namun juga merancang keilmuan yang bisa digunakan dalam mempertahankan eksistensi Islam dengan wajah yang lebih humanis sehingga permasalahan yang sedang dihadapi umat Islam saat ini yaitu klaim radikalisme bisa musnah dari wajah Islam. selain itu juga memaknai kitab suci dari sisi ilmu pengetahuan dengan memunculkan berbagai bentuk tafsir dari para tokoh terkenal seperti tafsir sosial, tafsir ilmiah dan masih banyak lagi bentuk penafsiran yang lebih modernis.

\section{E. Kesimpulan}

Hukum tiga tahap Auguste Comte yang diawali dengan tahap teologis, metafisik dan pada tahap final yaitu positif. tahapan yang ditawarkan Comte ternyata juga bisa digunakan untuk melihat transformasi yang terjadi di pendidikan Islam.

Tahap teologis terjadi pada saat munculnya pesantren pertamakali berbentuk pesantren salaf yang fokus kajiannya hanya ada pada teologis atau sisi sisi kehidupan setelah kematian sampai ada klaim bahwa ilmu agama adalah ilmu wajib yang harus dipelajari manusia. kemudian tahap metafisik memperlihatkan mulai digunakannya akal budi untuk menjawab permasalahan yang terjadi pada manusia baik pada tataran teologis maupun ibadah dan muamalah.

Pada tahap metafisik juga memunculkan lembaga pendidikan yang sudah mau menggunakan sistem pendidikan diluar yang dikenali islam awal yaitu klasikal, dan juga munculnya lembaga pengelolaan keuangan berbasis syariah. kemudian tahap positif dimana manusia sudah mempertimbangkan fakta ilmiah dalam menyelesaikan permasalahan keislaman yaitu munculnya tawaran pemaknaan islam yang humanis seperti pluralisme dan islam nusantara. 
Munculnya lembaga pendidikan tinggi keislaman juga menjadi wadah digodognya jawaban-jawaban ilmiah oleh para akademisi yang memiliki kualifikasi dan kompetensi profesional.

\section{BIBLIOGRAFI}

Anam, S. (2017). Karakteristik Dan Sistem Pendidikan Islam: Mengenal Sejarah Pesantren, Surau Dan Meunasah Di Indonesia. JALIE; Journal of Applied Linguistics and Islamic Education, 1(1), 146-167.

Arifin, S. (2018). Intelektualisme Profetik: (Respons terhadap Isu-isu Kontemporer di Seputar HAM, Radikalisme, Ekologi, dan Pendidikan). Malang: UMMPress.

Arifin, Z. (2012). Perkembangan pesantren di Indonesia. Jurnal Pendidikan Agama Islam, 9(1), 40-53.

Astini, K. Y. W., \& Arsadi, P. E. (2021). Perkembangan Akal Budi Manusia Pada Zaman Positifistik Dalam Perspektif Auguste Comte. Vidya Darśan: Jurnal Mahasiswa Filsafat Hindu, 2(2), 179-188.

Chabibi, M. (2019). Hukum Tiga Tahap Auguste Comte dan Kontribusinya terhadap Kajian Sosiologi Dakwah. NALAR: Jurnal Peradaban Dan Pemikiran Islam, 3(1), 14-26.

Daulay, H. P. (2019). Pendidikan Islam di Indonesia: Historis dan Eksistensinya. Kencana.

Haq, A. F. (2020). PEMIKIRAN TEOLOGI TEOSENTRIS MENUJU ANTROPOSENTRIS HASAN HANAFI. Jurnal Ilmiah Spiritualis: Jurnal Pemikiran Islam Dan Tasawuf, 6(2), 159-190.

Hariadi. (2015). EVOLUSI PESANTREN; Studi Kepemimpinan Kiai Berbasis Orientasi ESQ. Penerbit $\backslash \&$ Distribusi, LKiS Yogyakarta.

Hasanah, U, Suatuti, E., \& Rahayu, D. (2020). Buku Ajar Teori Hukum. Surabaya: SCOPINDO MEDIA PUSTAKA. Retrieved from https://books.google.co.id/books?id=YIrUDwAAQBAJ

Hasanah, Ulfatun. (2019). Kontribusi Pemikiran Auguste Comte (Positivisme) Terhadap Dasar Pengembangan Ilmu Dakwah. Al-I'lam: Jurnal Komunikasi Dan Penyiaran Islam, 2(2), 70-80.

Huda, M. (2020). Perbandingan Sistem Hukum. CV Cendekia Press.

Ibrahim, R. (2014). Eksistensi pesantren Salaf di tengah arus pendidikan modern. Analisa: Journal of Social Science and Religion, 21(2), 253-263.

Idris, M., Willya, E., \& Rumondor, P. (2020). Orientasi Pendidikan Islam. Yogyakarta: Deepublish.

Maulana, U. M. M. (2009). Auguste Comte Dan Ide Positivismenya. Jurnal Al-Fath, $1,32-39$.

$\overline{\text { Al-Madãris, Volume 2 (2), } 2021}$ 
Moko, C. W. (2017). Pluralisme Agama Menurut Nurcholish Madjid (1939-2005) dalam Konteks Keindonesiaan. Jurnal Intelektualita, 6(1).

Mubarak, H. A. Z. (2019). Sistem Pendidikan di Negeri Kangguru: Studi Komparatif Australia dan Indonesia. zakimu.com.

Munir, M. (2018). Filsafat Sejarah. Yogyakarta: UGM PRESS.

Muzakir, A. (2017). Transformasi pendidikan islam di Jambi: Dari Madrasah ke pesantren. Islam Realitas: Journal of Islamic and Social Studies, 3(1), 8-20.

Nawawi, H. H. (2005). Metode penelitian bidang sosial.

Nurianto Rachmad Soepadmo. (2020). Buku Ajar Filsafat Hukum. Sidoarjo: Zifatama Jawara.

PERATURAN PEMERINTAH REPUBLIK INDONESIA NOMOR 55 TAHUN 2007. (n.d.).

Permana, F. E. (2019). Literasi Digital di Pesantren Masih Perlu Ditingkatkan | Republika Online. Retrieved August 21, 2021, from Republika website: https://republika.co.id/berita/dunia-islam/islamnusantara/puw4bf320/dunia-islam/islam-nusantara/19/07/19/puvwko458 literasi-digital-di-pesantren-masih-perlu-ditingkatkan

PUSARAN, S. U. P. T. D. (2018). Kajian Poskolonial Gerakan Pemikiran dan Sikap Ulama Pesantren Tegalsari dalam Pusaran Konflik Multidimensional Di Jawa (1742-1862). Jurnal Theologia, 29(1), 189-214.

Sholehuddin, M. S. (2019). ANGKA PARTISIPASI KULIAH MASYARAKAT JAWA TENGAH TERHADAP PTKIN TAHUN 2015-2017.

Solichin, M. M. (2015). Kebertahanan Pesantren Tradisional Menghadapi Modernisasi Pendidikan. KARSA: Journal of Social and Islamic Culture, 22(1), 93113.

Sriyani. (2020). Perubahan Sosial Budaya. Batu: Literasi Nusantara.

Sudrajat, A. (2018). Pesantren sebagai Transformasi Pendidikan Islam di Indonesia. Vicratina: Jurnal Pendidikan Islam, 2(2), 64-88.

Sugiyono. (2008). Metode penelitian pendidikan: (pendekatan kuantitatif, kualitatif dan $R$ l $\sim D)$. Alfabeta.

Suryono, A. (2019). Teori dan Strategi Perubahan Sosial. Bumi Aksara.

Syarifuddin, N. (2017). Madrasah Sebagai Bentuk Transformasi Pendidikan Islam Di Indonesia. Al-Ibrah, 2(2), 25-54.

Tempo, P. D. dan A. (2020). Wajah Islam Nusantara. Tempo Publishing.

Tohir, K., \& M. Syukri Azwar Lubis. (2020). MODEL PENDIDIKAN PESANTREN

$\overline{\text { Al-Madãris, Volume 2 (2), } 2021}$ 
SALAFI. SCOPINDO MEDIA PUSTAKA.

Zuhriy, M. S. (2011). Budaya pesantren dan pendidikan karakter pada pondok pesantren salaf. Walisongo: Jurnal Penelitian Sosial Keagamaan, 19(2), 287-310. 